\title{
Hepatic Angiosarcoma: Clinicopathologic Study With an Investigation of ROS1 Gene Rearrangements
}

\author{
HERA JUNG ${ }^{1}$, HAN-NA KIM ${ }^{1}$, YUNJEONG JANG ${ }^{1}$, CHEOL-KEUN PARK ${ }^{1,2}$, \\ SO-HYUN SHIN ${ }^{1}$ and SANG YUN HA ${ }^{1}$ \\ ${ }^{1}$ Department of Pathology and Translational Genomics, Samsung Medical Center, \\ Sungkyunkwan University School of Medicine, Seoul, Republic of Korea; \\ ${ }^{2}$ Anatomic Pathology Reference Lab, Seegene Medical Foundation, Seoul, Republic of Korea
}

\begin{abstract}
Background/Aim: Primary hepatic angiosarcoma (PHA) is a rare disease entity with variable morphologic features. Recent findings regarding ROS1 gene rearrangements in PHA may lead to new targeted therapies. Patients and Methods: Thirteen cases (4 resected specimens and 9 biopsy samples) underwent histologic review and morphologic patterns were classified according to a previous study as 1) sinusoidal, 2) peliotic, 3) vasoformative, and 4) solid (epithelioid/spindled). ROS1 immunohistochemistry and investigation of the presence of a ROS1 fusion gene by reverse transcription-polymerase chain reaction were performed in available cases. Results: Eight of 13 cases $(62 \%)$ showed vasoformative patterns. Three cases (23\%) were classified as sinusoidal and two (15\%) as solid patterns. Mortality rate was 90\% (9/10) except for three patients lost in follow up. Only one patient is still alive and has survived for 8 months with the disease. All cases tested did not have ROS1 expression (0/9) or a ROS1 fusion gene (0/4). Conclusion: We report 13 cases of PHA with $90 \%$ mortality. Vasoformative PHA is the most common histologic type. New findings on ROS1 fusion gene rearrangements could lead to the development of novel targeted therapeutics for PHA patients with dismal prognosis.
\end{abstract}

Angiosarcoma is a malignant vascular tumor arising from vessel endothelial cells. The liver is the second most

This article is freely accessible online.

Correspondence to: Sang-Yun Ha, MD, Ph.D., Department of Pathology and Translational Genomics, Samsung Medical Center, Sungkyunkwan University School of Medicine, 81 Irwon-ro, Gangnam-gu, Seoul 06351, Republic of Korea. Tel: +82 234106398, Fax: +82 234100025, e-mail: sangyun.ha@skku.edu

Key Words: Liver, cancer, angiosarcoma, ROS1, prognosis, target therapy. common angiosarcoma site (1). However, primary hepatic angiosarcoma (PHA) is quite rare, comprising less than $2 \%$ of all primary hepatic tumors (2). A previous multiinstitutional study of about 44 hepatic angiosarcoma cases revealed a poor prognosis with 5.8 months median overall survival and only two patients achieving 5-year survival (3).

Although no standard treatment has been established, surgical resection is the only treatment option that can provide long-term survival (4). According to a previous review article, partial hepatectomy in small size tumors (particularly, $<10 \mathrm{~cm}$ ) is a favorable factor (5). Chemotherapy can be an option for unresectable cases but liver transplantation is not recommended (5). Therefore, if possible, molecular therapy can be an alternative for the treatment of advanced tumors or those larger than $10 \mathrm{~cm}$. Little is known about the genetic abnormalities in hepatic angiosarcoma, but a recent study by Marks et al. reported the first case of a ROS1 fusion gene rearrangement with $G O P C / F I G(6)$. Crizotinib has now been used for pulmonary non-small cell carcinoma with a ROS1 rearrangement. In hepatic angiosarcoma with ROSI rearrangement, ROS1 tyrosine kinase inhibitors including crizotinib can be an optional treatment. A CEP85L-ROS1 fusion was also identified in another study (7). Therefore, the presence of a ROS1 gene fusion in this disease should be further investigated.

Variations in hepatic angiosarcoma have been found at the microscopic level in several studies. Yasir et al. from the Mayo clinic, classified the morphologic patterns of 21 hepatic angiosarcoma cases into two major groups that considered whether the tumor has mass formation or not (8). "Massforming" tumors are further subclassified as vasoformative or non-vasoformative by the recognition of vascular space on microscopic examination (8). Non-vasoformative solid tumors can have epithelioid/or spindled morphology (8). "Non-massforming" tumors can be divided into a "sinusoidal" or "peliotic" pattern (8). Overall four main histologic growth patterns have been suggested: 1) sinusoidal, 2) peliotic, 3) vasoformative, and 4) solid (epithelioid/spindled) (8). 
Table I. Clinicopathologic data of 13 hepatic angiosarcomas.

\begin{tabular}{|c|c|c|c|c|c|c|c|c|c|}
\hline $\begin{array}{l}\text { Case } \\
\text { No. }\end{array}$ & $\begin{array}{l}\text { Gender/Age } \\
\text { (year) }\end{array}$ & Location/Number & Symptom & Management & $\begin{array}{c}\text { Metastasis } \\
\text { (Detected time } \\
\text { from diagnosis) }\end{array}$ & Status & $\begin{array}{l}\text { Survival } \\
\text { period }\end{array}$ & $\begin{array}{l}\text { Morphological } \\
\text { pattern }\end{array}$ & $\begin{array}{c}\text { ROS1 } \\
\text { (IHC/RT-PCR) }\end{array}$ \\
\hline 1 & $\mathrm{M} / 57$ & S4 \& S3/Multiple & $\begin{array}{l}\text { Epigastric } \\
\text { discomfort }\end{array}$ & Left lobectomy & $\begin{array}{l}\text { Multiple } \\
\text { (2 months) }\end{array}$ & Dead & 2 months & Vasoformative & $\begin{array}{l}\text { Negative/ } \\
\text { Failed }\end{array}$ \\
\hline 2 & $\mathrm{~F} / 2$ & Both lobes/Multiple & $\begin{array}{l}\text { Abdominal } \\
\text { distension }\end{array}$ & $\begin{array}{l}\text { Liver transplantation, } \\
\text { postoperative } \\
\text { chemotherapy and } \\
\text { auto-PBSCT }\end{array}$ & $\begin{array}{l}\text { Multiple } \\
\text { (1 month) }\end{array}$ & Dead & 3 years & $\begin{array}{l}\text { Vasoformative } \\
\text { with spindled }\end{array}$ & $\begin{array}{l}\text { Negative/ } \\
\text { Negative }\end{array}$ \\
\hline 3 & $\mathrm{M} / 52$ & $\begin{array}{c}\text { S4, } 5,8 \\
\& \text { S6/Multiple }\end{array}$ & $\underset{\text { pain }}{\text { Abdominal }}$ & $\begin{array}{c}\text { Trisegmentectomy } \\
\text { (Postoperative chemotherapy } \\
\text { refuse) } \\
\text { (local recurrence) }\end{array}$ & py & Dead & 6 months- & $\begin{array}{c}\text { Solid } \\
\text { (spindled) }\end{array}$ & $\begin{array}{l}\text { Negative/ } \\
\text { Negative }\end{array}$ \\
\hline 4 & $\mathrm{M} / 60$ & S7/Single & None & $\begin{array}{l}\text { Liver transplantation } \\
\text { and postoperative } \\
\text { radiation therapy }\end{array}$ & $\begin{array}{c}\text { Bone } \\
\text { (11months) }\end{array}$ & Dead & 11 months & Sinusoidal & $\begin{array}{l}\text { Negative/ } \\
\text { Failed }\end{array}$ \\
\hline 5 & $\mathrm{~F} / 96$ & Both lobes/Multiple & $\begin{array}{l}\text { Abdominal } \\
\text { pain }\end{array}$ & $\begin{array}{c}\text { Supportive } \\
\text { treatment }\end{array}$ & None & Dead & 2 months & Solid (spindled) & $\begin{array}{l}\text { Negative/ } \\
\text { Negative }\end{array}$ \\
\hline 6 & $\mathrm{M} / 66$ & Right/Single & $\begin{array}{l}\text { Indigestion, } \\
\text { back pain }\end{array}$ & ND & None & Dead & 2 weeks & Vasoformative & Negative/ND \\
\hline 7 & $\mathrm{M} / 76$ & S5/Multiple & None & $\begin{array}{l}\text { Palliative chemotherapy } \\
\text { and paracentesis }\end{array}$ & None & Dead & 7 months & Vasoformative & $\begin{array}{l}\text { Negative/ } \\
\text { Negative }\end{array}$ \\
\hline 8 & $\mathrm{~F} / 67$ & S6/Multiple & RUQ pain & $\begin{array}{l}\text { ND (chemotherapy } \\
\text { refuse) }\end{array}$ & None & Dead & 5 months & Vasoformative & Negative/ND \\
\hline 9 & $\mathrm{M} / 83$ & S5/Multiple & $\begin{array}{l}\text { Abdominal } \\
\text { distension }\end{array}$ & ND & Adrenal (initial) & Dead & 1 month & Sinusoidal & Negative/ND \\
\hline 10 & $\mathrm{~F} / 78$ & S8/Multiple & $\begin{array}{l}\text { Abdominal } \\
\text { distension }\end{array}$ & $\begin{array}{c}\text { Supportive } \\
\text { treatment }\end{array}$ & None & $\begin{array}{l}\text { Follow up } \\
\text { loss }\end{array}$ & 2 weeks & Vasoformative & $\mathrm{ND} / \mathrm{ND}$ \\
\hline 11 & $\mathrm{M} / 62$ & $\begin{array}{l}\text { Both lobes/ } \\
\text { Multiple }\end{array}$ & Weight loss & $\begin{array}{c}\text { Palliative } \\
\text { chemotherapy }\end{array}$ & $\begin{array}{l}\text { Intrahepatic } \\
\text { metastasis } \\
\text { (initial) }\end{array}$ & $\begin{array}{l}\text { Alive } \\
\text { with } \\
\text { disease }\end{array}$ & 8 months & Vasoformative & $\mathrm{ND} / \mathrm{ND}$ \\
\hline 12 & $\mathrm{M} / 77$ & Right/Two & None & $\begin{array}{c}\text { Palliative } \\
\text { chemotherapy }\end{array}$ & None & $\begin{array}{l}\text { Follow up } \\
\text { loss }\end{array}$ & 5 months & Vasoformative & $\mathrm{ND} / \mathrm{ND}$ \\
\hline 13 & $\mathrm{M} / 73$ & Left/Multiple & None & $\begin{array}{l}\text { Supportive } \\
\text { treatment }\end{array}$ & None & $\begin{array}{l}\text { Follow up } \\
\text { loss }\end{array}$ & $\begin{array}{c}1 \text { year } \\
8 \text { months }\end{array}$ & Sinusoidal & $\mathrm{ND} / \mathrm{ND}$ \\
\hline
\end{tabular}

Survival period: from initial histologic diagnosis to last follow up (dead or alive). ND: Not done; PBSCT: peripheral blood stem cell transplantation; IHC: immunohistochemistry; RT-PCR: reverse transcription polymerase chain reaction.

In our study, we aimed to describe morphologic findings in 13 cases of PHA presented at a single institute over 19 years, accompanied by clinicopathological analysis. Additionally, our study investigated ROS1 gene rearrangements by immunohistochemical and molecular analyses.

\section{Patients and Methods}

Patient selection. From June 2000 to March 2019, the pathology database of Samsung Medical Center, Seoul, Korea, was searched for all biopsy and resected specimens identified as 'angiosarcoma' of the liver. In total, 13 cases were selected and hematoxylin and eosin stained slides were reviewed. After examining the residual formalin-fixed paraffin-embedded (FFPE) blocks, nine of them had sufficient tissue for further ROS1 immunohistochemical analysis and six for molecular analysis. Electronic medical records were reviewed for clinical information, including demographic features, radiologic findings, treatment history, and clinical outcomes. The
Institutional Review Board of the Samsung Medical Center approved this study and waived the informed consent.

Histologic classification. Histologic review of 13 cases was performed, and cases were classified according to four main classifications: 1) sinusoidal, 2) peliotic, 3) vasoformative, and 4) solid (epithelioid/spindled), as suggested by Yasir et al. (8).

ROS1 immunohistochemistry. ROS1 immunohistochemical studies were performed on 4- $\mu$ m thick representative sections of FFPE tissues. Appropriate samples were obtained from nine cases of hepatic angiosarcoma. A Bond 3 Automated Immunostainer (Leica Microsystems, IL, USA) was used to retrieve antigen with ER2 solution for $20 \mathrm{~min}$, and the sections were incubated with anti-ROS1 antibody (clone: D4D6, 1:100; Cell Signaling Technology, Danvers, MA, USA).

Reverse transcription-polymerase chain reaction (RT-PCR) for ROS1 fusion gene detection. Total RNA was prepared using a RNeasy FFPE kit (Qiagen, MD, USA) according to the manufacturer's protocols. A 


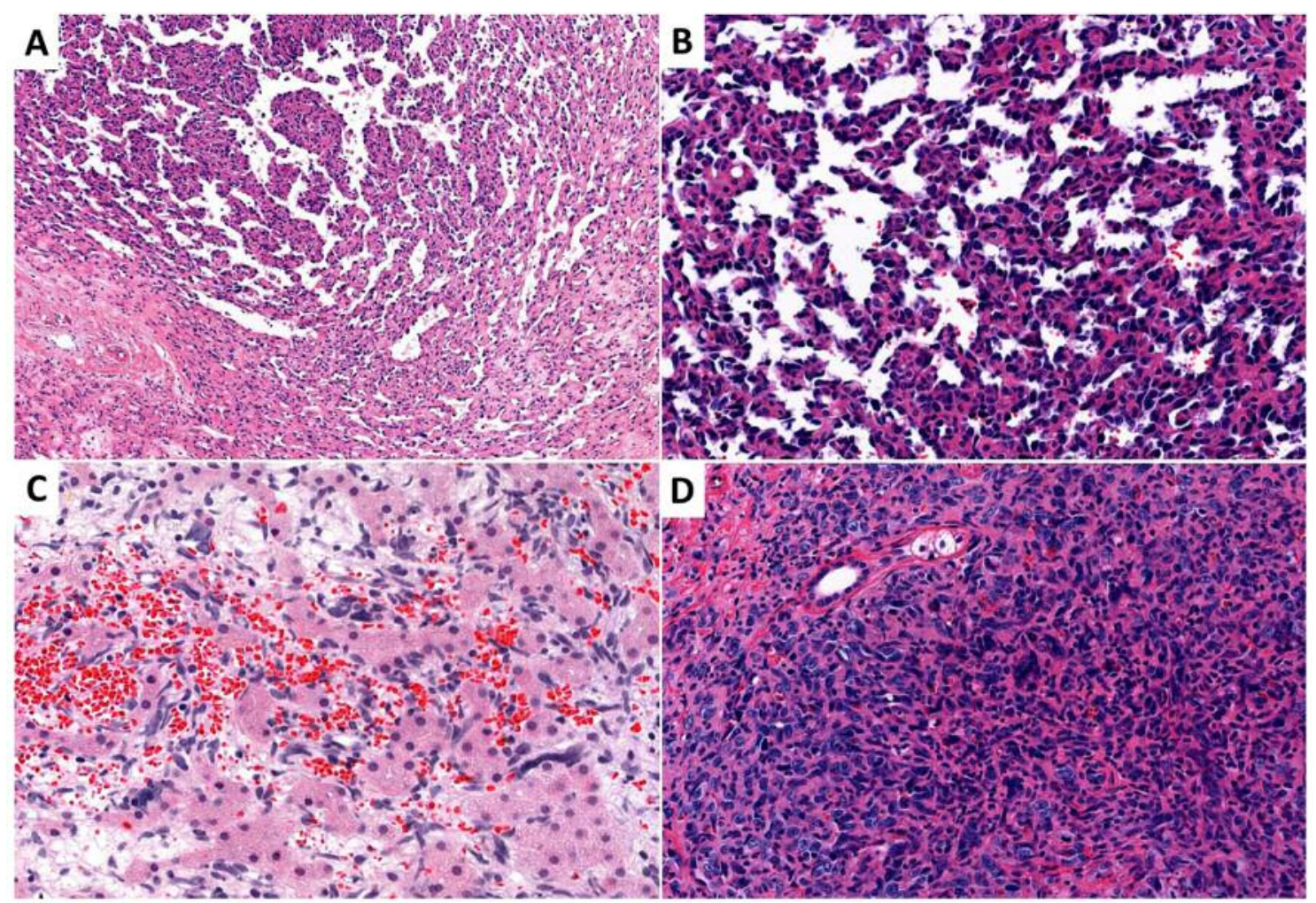

Figure 1. Histologic classification of primary hepatic angiosarcoma. (A, B) Vasoformative pattern, (C) sinusoidal pattern, and (D) solid pattern.

total of $2 \mu \mathrm{g}$ of RNA was reverse transcribed using random hexamer and SuperScript III Reverse Transcriptase (Invitrogen, ThermoFisher Scientific, Waltham, MA, USA). RT-PCR amplification reactions were performed using the following conditions: an initial denaturation for $10 \mathrm{~min}$ at $95^{\circ} \mathrm{C}$ and then 40 cycles for $30 \mathrm{sec}$ at $95^{\circ} \mathrm{C}, 30 \mathrm{sec}$ at $59^{\circ} \mathrm{C}$, and $60 \mathrm{sec}$ at $72^{\circ} \mathrm{C}$, followed by $72^{\circ} \mathrm{C}$ for $10 \mathrm{~min}$. The primers for the CEP85L-ROS1 fusion gene were 5'-GCCAACAAGATG AGATTGACAGA-3' (forward) and 5'-TAAGCACTGTCACC CCTTCC-3' (reverse). The primers for the $F I G-R O S 1(S)$ fusion gene were 5'-CCCTTCGTAGACATATAGCTGTT-3' (forward) and 5'CCACTGCTGTTCCTTCATACA-3' (reverse). The primers for the $F I G-R O S 1(L)$ fusion gene were 5'-TGGACATCGTTACCGTTTGTA3' (forward) and 5'- GCATTAGCCAGGCCTACTC-3' (reverse).

\section{Results}

Clinicopathological characteristics. The clinicopathological features of 13 angiosarcomas are summarized in Table I. Nine of the 13 patients were male and the median age at initial histologic diagnosis was 67 years old. Eleven patients had multiple masses at the initial radiologic examination. Nine patients had symptoms at the first visit, including abdominal pain and distension. Four of the 13 underwent surgical treatment, which included two liver transplantations, one lobectomy, and one trisegmentectomy. The patient who had the trisegmentectomy experienced local recurrence after the operation but refused further chemotherapy. Chemotherapy was received by four patients including one operated patient. Treatment was not possible in two patients due to the advanced stage of disease; one of these patients died 2 weeks and one at 1 month subsequent to their initial diagnoses. One patient refused treatment and died after 5 months. Initial work up findings revealed that two patients had metastatic lesions, one patient had adrenal metastasis and the other had multiple intrahepatic metastasis. After the diagnosis, multiple metastases were identified in two patients (after 2 months and 1 month). One patient who underwent transplantation and postoperative radiation therapy developed bone metastasis after 11 months. Nine died of disease progression, one patient is still alive with the disease (Case No. 11) after 8 months, and three (Case No. 10, 12, and 13) were lost to follow up.

Histological classification. Eight of the 13 cases $(61.5 \%)$ showed a vasoformative pattern (Table I). They had vessel formation without parenchymal liver tissue (Figure 1A and B). Between the vascular forming area, fibrotic stroma was identified in most cases. One of the cases had a focal solid area with spindled morphology. There were three cases of sinusoidal pattern and two solid tumors with a spindled pattern. In our case series, the peliotic type was not found. 

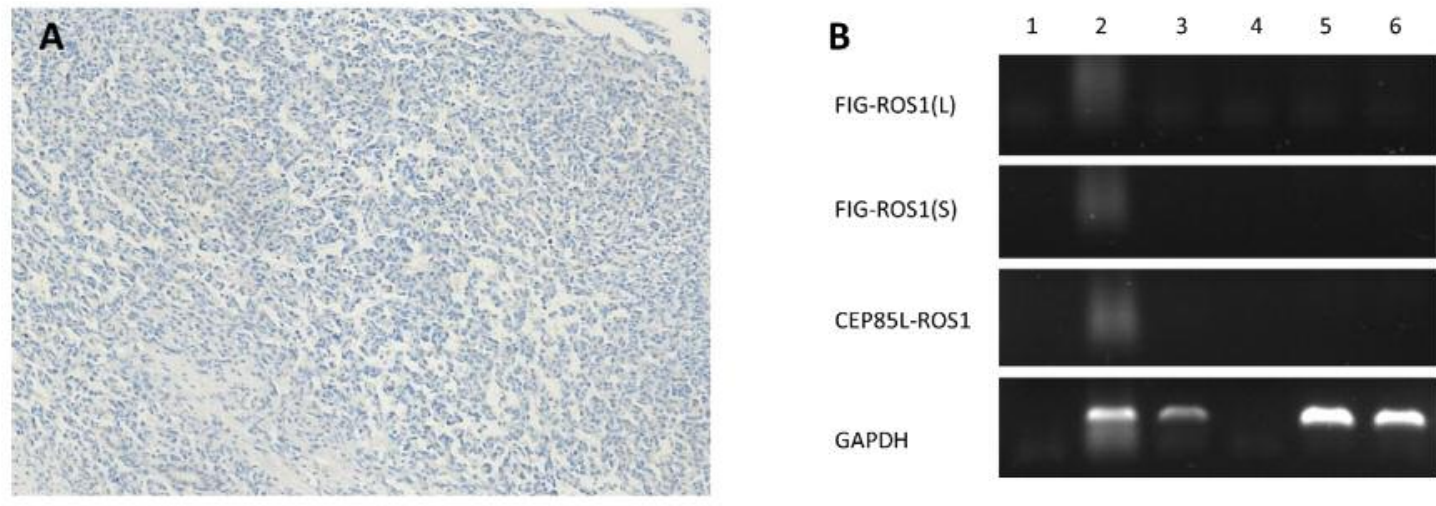

Figure 2. ROS1 immunohistochemistry (A) and reverse transcription-polymerase chain reaction for the ROS1 fusion gene (B). ROS1 expression or the ROS1-fusion gene was not detected in any of the samples tested.

The sinusoidal type showed dilated sinusoidal spaces with congestion of red blood cells (Figure 1E). Atypical cells with hyperchromasia were lined along the sinusoids and hepatic parenchyma was identified between the spaces. Two solid tumors had spindled morphology with mild whorling or storiform architecture (Figure 1F).

ROS1 immunohistochemistry (IHC) and RT-PCR for ROS1 fusion gene detection. Nine cases had sufficient remnant tissue for further study. ROS1 IHC was used to assess them, and all cases were negative (Figure 2A). After immunohistochemistry, RT-PCR was used to investigate the presence of ROS1 fusion transcripts in six cases. Two failed due to inappropriate RNA quality that prevented cDNA synthesis, and the remaining four cases did not indicate the presence of a FIG-ROS1 or CEP85L-ROS1 fusion (Figure 2B).

\section{Discussion}

In this study, we reviewed histopathologic features of 13 PHAs over 19 years at our institute, and classified them into four categories, 1) sinusoidal, 2) peliotic, 3) vasoformative, and 4) solid (epithelioid/spindled), that were suggested by Yasir et al. (8). As a result, the most common histologic type was vasoformative (8 of 13 cases). Three of the PHAs were classified as sinusoidal, and the remaining two cases as solid. There was no typical peliotic type PHA in this study. PHA has morphologic diversity, thus pathologists should consider the variation of histologic features when facing vascular or mesenchymal tumors with suspicion of PHA. Clinical data were similar to previous studies of PHA. Males were predominant. Only one patient remains alive with the disease and nine of the 13 patients have died. The mortality rate was 90\% (9 of 10), with the exception of three patients who were lost to follow up. The treatment of PHA has not been defined. In previous studies, complete surgical resection was shown to be the key to improving prognosis $(9,10)$. In the cases we studied, two patients went through surgical resection, but they died within 6 months with multiple metastases and local recurrence after surgery. Transplantation is now abandoned due to the high recurrence rate and poor survival (11) and PHA is now a contraindication to liver transplantation by the European Liver Transplant Registry (12). Two patients (Cases No. 2 and 4) in this study underwent transplantation in 2001 and 2008, before the recommendation. They died of the disease after postoperative chemotherapy with auto-peripheral blood stem cell transplantation and postoperative radiation therapy. Palliative chemotherapy was performed in three patients. One of the patients remains alive and has survived with the disease for 8 months so far, although intrahepatic multiple metastatic lesions were detected at the initial diagnosis. The median survival period was 5 months. The overall prognosis of PHA is dismal, compared to hepatic hemangioendothelioma with a mortality rate of $25 \%$ (13).

Recently, the ROSI fusion genes with GOPC/FIG (6) and CEP85L (7) have been reported in angiosarcomas. We can anticipate the application of ROS1-targeted therapy in angiosarcomas with poor prognosis. Therefore, we tested ROS1 IHC in nine cases and RT-PCR for FIG-ROS1 or ROS1-CEP85L fusion transcripts in four cases, but could not find either ROS1 expression or the ROS1-fusion gene. The major limitation of this study is that we performed RT-PCR without a positive control sample. FIG-ROS1 or CEP85L$R O S 1$ is a very rare variant, that have been reported only in a few previous reports, and we could not find any positive control harboring such variants. Actually, the results of IHC and RT-PCR for ROS1 rearrangements have been reported to be highly concordant, and IHC is regarded as a reliable screening method for fusion gene detection (14-16). In our lab, we perform IHC, RT-PCR, and next generation sequencing in daily practice, and the results of these modalities are highly concordant. In our study, all tested 
samples were IHC-negative, so they could also be negative for a ROS1 rearrangement. Further studies regarding the ROS1 fusion gene are necessary in more PHAs.

\section{Conclusion}

We report 13 cases of PHAs with $90 \%$ mortality. Vasoformative PHA is the most common histologic type. Pathologists should consider variable morphological patterns including sinusoidal, solid (epithelioid/spindled), and peliotic type, in addition to vasoformative type. Although all cases tested did not express ROS1 or a ROS1 fusion gene, new findings on ROS1 fusion gene rearrangements could be key for the development of targeted therapy for PHA with dismal prognosis.

\section{Conflicts of Interest}

None of the Authors has any conflicts of interest to declare regarding this study.

\section{Authors' Contributions}

Conception and design: HJ, SYH; Acquisition of data: HJ, SS, CP, SYH; Analysis and interpretation of data: HJ, SYH; Drafting the article: HJ, SYH; Revising and final approval of the article to be published: HJ, HK, YJ, SS, CKP, SYH.

\section{Acknowledgements}

This study was funded by the Samsung Medical Center intramural grant (\#SMO1161731) and the Basic Science Research Program through the National Research Foundation of Korea (NRF), funded by the Ministry of Education (NRF-2017R1C1B5017890).

\section{References}

1 Naka N, Ohsawa M, Tomita Y, Kanno H, Uchida A and Aozasa $\mathrm{K}$ : Angiosarcoma in Japan. A review of 99 cases. Cancer 75(4): 989-996, 1995. PMID: 7842420. DOI: 10.1002/10970142(19950215)75:4<989::aid-cncr2820750414>3.0.co;2-k

2 Molina E and Hernandez A: Clinical manifestations of primary hepatic angiosarcoma. Dig Dis Sci 48(4): 677-682, 2003. PMID: 12741455. DOI: $10.1023 / \mathrm{a}: 1022868221670$

3 Wilson GC, Lluis N, Nalesnik MA, Nassar A, Serrano T, Ramos E, Torbenson $\mathrm{M}$, Asbun $\mathrm{HJ}$ and Geller DA: Hepatic angiosarcoma: A multi-institutional, international experience with 44 cases. Ann Surg Oncol 26(2): 576-582, 2019. PMID: 30456677. DOI: 10.1245/s10434-018-7062-9

4 Matthaei H, Krieg A, Schmelzle M, Boelke E, Poremba C, Rogiers X, Knoefel WT and Peiper M: Long-term survival after surgery for primary hepatic sarcoma in adults. Arch Surg 144(4): 339-344; discussion 344, 2009. PMID: 19380647. DOI: 10.1001/archsurg. 2009.30

5 Li DB, Si XY, Wan T and Zhou YM: A pooled analysis of treatment and prognosis of hepatic angiosarcoma in adults. Hepatobiliary Pancreat Dis Int 17(3): 198-203, 2018. PMID: 29724676. DOI: 10.1016/j.hbpd.2018.04.005
6 Marks EI, Pamarthy S, Dizon D, Birnbaum A, Yakirevich E, Safran H and Carneiro BA: ROS1-GOPC/FIG: a novel gene fusion in hepatic angiosarcoma. Oncotarget 10(2): 245-251, 2019. PMID: 30719217. DOI: 10.18632/oncotarget.26521

7 Giacomini CP, Sun S, Varma S, Shain AH, Giacomini MM, Balagtas J, Sweeney RT, Lai E, Del Vecchio CA, Forster AD, Clarke N, Montgomery KD, Zhu S, Wong AJ, van de Rijn M, West RB and Pollack JR: Breakpoint analysis of transcriptional and genomic profiles uncovers novel gene fusions spanning multiple human cancer types. PLoS Genet 9(4): e1003464, 2013. PMID: 23637631. DOI: 10.1371/journal.pgen.1003464

8 Yasir S and Torbenson MS: Angiosarcoma of the liver: clinicopathologic features and morphologic patterns. Am J Surg Pathol 43(5): 581-590, 2019. PMID: 30986799. DOI: 10.1097/ PAS.0000000000001228

9 Duan XF and Li Q: Primary hepatic angiosarcoma: a retrospective analysis of 6 cases. J Dig Dis 13(7): 381-385, 2012. PMID: 22713088. DOI: $10.1111 / \mathrm{j} .1751-2980.2012 .00600 . \mathrm{x}$

10 Weitz J, Klimstra DS, Cymes K, Jarnagin WR, D'Angelica M, La Quaglia MP, Fong Y, Brennan MF, Blumgart LH and Dematteo RP: Management of primary liver sarcomas. Cancer 109(7): 1391-1396, 2007. PMID: 17315167. DOI: 10.1002/ cncr.22530

11 Orlando G, Adam R, Mirza D, Soderdahl G, Porte RJ, Paul A, Burroughs AK, Seiler CA, Colledan M, Graziadei I, Garcia Valdecasas JC, Pruvot FR, Karam V and Lerut J: Hepatic hemangiosarcoma: an absolute contraindication to liver transplantation--the European Liver Transplant Registry experience. Transplantation 95(6): 872-877, 2013. PMID: 23354302. DOI: $10.1097 /$ TP.0b013e318281b902

12 Bonaccorsi-Riani E and Lerut JP: Liver transplantation and vascular tumours. Transpl Int 23(7): 686-691, 2010. PMID: 20492619. DOI: 10.1111/j.1432-2277.2010.01107.x

13 Jung H, Kim HN, Jang Y, Park CK and Ha SY: CAMTA-1 Expression in 24 cases of hepatic epithelioid hemangioendothelioma in a single institute: diagnostic utility for differential diagnosis from hepatic angiosarcoma. In Vivo 33(6): 2293-2297, 2019. PMID: 31662570. DOI: 10.21873/invivo. 11736

14 Rimkunas VM, Crosby KE, Li D, Hu Y, Kelly ME, Gu TL, Mack JS, Silver MR, Zhou X and Haack H: Analysis of receptor tyrosine kinase ROS1-positive tumors in non-small cell lung cancer: identification of a FIG-ROS1 fusion. Clin Cancer Res 18(16): 4449-4457, 2012. PMID: 22661537. DOI: 10.1158/1078-0432.CCR-11-3351

15 Shan L, Lian F, Guo L, Qiu T, Ling Y, Ying J and Lin D: Detection of ROS1 gene rearrangement in lung adenocarcinoma: comparison of IHC, FISH and real-time RT-PCR. PLoS One 10(3): e0120422, 2015. PMID: 25742289. DOI: 10.1371/ journal.pone.0120422

16 Shaw AT, Ou SH, Bang YJ, Camidge DR, Solomon BJ, Salgia R, Riely GJ, Varella-Garcia M, Shapiro GI, Costa DB, Doebele RC, Le LP, Zheng Z, Tan W, Stephenson P, Shreeve SM, Tye LM, Christensen JG, Wilner KD, Clark JW and Iafrate AJ: Crizotinib in ROS1-rearranged non-small-cell lung cancer. N Engl J Med 371(21): 1963-1971, 2014. PMID: 25264305. DOI: 10.1056/NEJMoa1406766

Received February 7, 2020

Revised March 2, 2020

Accepted March 3, 2020 